\title{
ТСM \\ COVID-19 AND SCIENCE COMMUNICATION \\ COVID-19 and (hydroxy)chloroquine: a dispute over scientific truth during Bolsonaro's weekly Facebook live streams
}

\section{Ana Carolina Monari, Allan Santos and Igor Sacramento}

\section{Abstract}

Keywords

DOI

Introduction
As successive studies have shown that chloroquine and hydroxychloroquine are ineffective in treating COVID-19, this article investigates how the Brazilian president, Jair Bolsonaro, disputes the truth around science to convince the population that these drugs can save lives, preserve jobs and restore economic growth. Using Charaudeau's theory [2007; 2010] as a methodological framework, as well as understanding that right-wing populism has embodied post-truth communication as a distinctive feature of contemporary politics, we observed Bolsonaro's weekly Facebook live streams - known as 'lives' - for 14 weeks, identifying them as a communicative device that offers Bolsonaro the material conditions to interact directly with his public. Finally, we structured our analysis according to the three most common themes - questioning delays due to an insistence on scientific methodology, overvaluation of personal experiences and emphasis on individuals' freedom of choice - to observe the emotional images and discursive scenarios the Brazilian president stages to produce the intended pathemic effects of his discourse: hope and urgency; trust and distrust; freedom and polarization.

Health communication; Science and media; Science communication in the developing world

https://doi.org/10.22323/2.19070203

Submitted: 1st July 2020

Accepted: 28th September 2020

Published: 14th December 2020
The World Health Organization (WHO) warned in December 2019 of the emergence of a new type of coronavirus that was responsible for the growing number of pneumonia cases in Wuhan, Hubei province, in the People's Republic of China. With the significant increase in the number of cases and its global spread, COVID-19 - the name of the disease caused by the new coronavirus (SARS-CoV-2) — was characterized by the WHO as a pandemic on March 11, 2020.

In Brazil, the first official occurrence of COVID-19 was recorded on February 26, 2020. Since then, federal, state and municipal agencies have been monitoring the 
disease's progress in the country and seeking solutions to combat the problem. A vaccine has not been developed yet, but there are initiatives around the world to test chemical substances available on the market in order to provide specific treatments for the new disease.

The current president of Brazil, Jair Messias Bolsonaro, through his social media accounts and in the press, has demonstrated the duality of measures taken to contain the virus and their impact on the economy. He criticized social isolation policies and the state governors who adopted them, saying that the consequences of stopping economic activities to safeguard public health could lead to unemployment and the closure of numerous companies.

In late March 2020, Bolsonaro began to promote chloroquine and hydroxychloroquine as viable treatments for COVID-19. In his weekly Facebook live streams, the president spoke about the benefits of the substances, based on reports of patients who claimed that they had been cured by these medications. Although the drugs are normally prescribed for malaria, arthritis, lupus erythematosus and photosensitive diseases, after the president's pronouncement there was an increase in the demand for them, causing them to disappear from drugstore shelves throughout Brazil. The problem is that there are a significant number of national and international scientific studies proving that the substances are ineffective for treating COVID-19 and that taking them may even aggravate patients' health. ${ }^{1}$ Still, scientific facts did not prevent the Brazilian Department of Health from publishing a protocol for the use of (hydroxy)chloroquine for treatment of individuals in all stages of the disease, including patients with mild symptoms, ${ }^{2}$ on May 20, 2020. The protocol suggests combining the two drugs with azithromycin and is a guideline for the Brazilian public health system.

The leader of the nation, therefore, focuses on two fronts when the subject is the coronavirus: 1) relaxation of social isolation measures, contrary to WHO recommendations (since social isolation is currently thought to be the only tool available to lessen the number of individuals infected); and 2) administration of (hydroxy)chloroquine to patients with COVID-19. These two narratives converge, since if there is an effective drug for the disease there is no need to restrict people's movements, nor temporary closure of commercial establishments, thus protecting the Brazilian economy. The drug was the source of strong disagreements between the president and his two former Health Secretaries, Luiz Henrique Mandetta and Nelson Teich, as both were against use of the drugs by individuals with mild COVID-19 symptoms. Because of differences of opinion, the first was dismissed and the second quit.

\footnotetext{
${ }^{1}$ Among them, the study published by the American College of Cardiology on March 29, 2020 (https:/ / bit.ly /3eYiBao), the CloroCOVID-19 announced on April 20, 2020 (https:/ / bit.ly/3fRHBRN), as well as the research published in the New England Journal of Medicine on May 7, 2020 (https:/ / bit.ly/2ZOLwJm), in the Journal of the American Medical Association on May 11, 2020 (https: / bit.ly/3juC3im) and in the British Medical Journal om May 15, 2020 (https:/ / bit.ly/2CGNqmy). The study published in The Lancet, on May 22, 2020, was later retracted and withdrawn from circulation by its authors after problems in their database were identified (https:/ / bit.ly/2CIWtn3). (visited on September 17, 2020).

${ }^{2}$ https:/ / bit.ly/2BIC291 (visited on May 21, 2020).
} 
This is not the first time that the Brazilian president has defended the administration of chemical and pharmaceutical compounds without scientific evidence. In 2016, as a congressman, he was one of the co-authors of a bill that would have provided access to synthetic phosphoethanolamine for cancer patients. The drug developed at the University of São Paulo Institute of Chemistry, in the city of São Carlos, was considered a possible cure for cancer, despite the complete lack of clinical tests in humans. The bill was approved and sanctioned by former President Dilma Rousseff, but the Brazilian Supreme Court overruled it a few days later [Monari, 2019].

\section{Objective}

The main objective of this article is to analyze the pathemic discursive strategies employed by Jair Bolsonaro in his weekly Facebook live streams, known colloquially as 'lives', to convince the population of the usefulness of taking chloroquine and hydroxychloroquine to treat COVID-19, despite studies indicating its inefficacy and the WHO not recommending its therapeutic use. In this context, we observe and analyze the Brazilian president's opportunistic use of science in the dispute over promoting these drugs for treating the new disease. What discursive strategies does he use to convince the public to take chloroquine and hydroxychloroquine? Is there a bias towards personal accounts rather than scientific facts? If so, how is this done?

\section{Methodology}

According to Charaudeau [2010], emotion must be seen from the perspective of the discursive effect engendered by the speech or act of language. In other words, the French linguist proposes studying emotion as an effect targeted (and not produced) by the enunciating subject, that is, as an effect that he intends to achieve through his discursive staging. In order to delimit the scope of the study of emotion in speech, Charaudeau [2010] calls these effects "pathemic discursive effects," explaining that he prefers the terms "pathos," "pathemic" and "pathemization," instead of emotion because of the insertion of "the analysis of the discourse of emotions in the lineage of rhetoric that since Aristotle has treated discourse from a perspective of aim and effects" [Charaudeau, 2010, p. 35].

Charaudeau [2010] lists three conditions for the production of the pathemic effect of the discourse: 1) a communicative device: the components of the communication contract, especially the purpose and identity, must predispose listeners and/or readers to the intended effect, because, as we have seen, it is the communication situation that emanates discursive instructions for the development of the act of influence in the linguistic processes; 2) a thematic field: the thematic field on which the act of language is based must foresee a universe of pathemization and produce a certain organization of the topics (sociodiscursive imaginary) to produce a pathemic effect; and 3) a space of strategy: the enunciative instance, or the enunciating subject, must, within the dramatization process, use discursive staging with a pathemization purpose, that is, the strategies must be organized to produce pathemic effects.

Using Charaudeau's theory $[2007 ; 2010]$ as a methodological framework, we will conduct our analysis in three steps. Firstly, we will observe Bolsonaro's weekly Facebook lives as a "communicative device" that offers the Brazilian president the 
material conditions to interact with his public and produce the intended pathemic effects. Thus, we transcribed the content of 14 episodes of the "Thursday Live streams with President Jair Bolsonaro," transmitted via his official Facebook profile, from February 26, 2020 (first confirmed COVID-19 case in Brazil) to May 21, 2020 (publication of the chloroquine and hydroxychloroquine expansion protocol by the Brazilian Department of Health). However, for this article we only consider the discourse during which Bolsonaro specifically addresses the drugs, which correspond to the Facebook lives streamed on: March 26, ${ }^{3}$ April 9, ${ }^{4}$ April 16, May $14^{6}$ and May 21, 2020.?

Secondly, our discussion will be structured according to the three most often recurring "thematic fields" that permeate Bolsonaro's weekly Facebook live streams: questioning delays in reaching a scientific consensus, overvaluation of personal experiences and an emphasis on individuals' freedom of choice. These three themes foresee the existence of a pathemic universe and suggest a certain topical structure suitable for causing the effects intended by the Brazilian president.

Finally, we will closely observe the "spaces of strategy" in which Bolsonaro builds emotional images and discursive scenarios for staging the targeted pathemic effects aimed at convincing the population of the benefits of using chloroquine and hydroxychloroquine to treat patients infected with the new coronavirus, despite the lack of scientific evidence.

Post-truth: emotions, the crisis of trust and populism
The set of events, such as the failure of trust in institutions and disinformation campaigns, as well as the advent of technology and social media, can be thought of as the trajectory that led to the emergence of post-truth [D'Ancona, 2018]. According to the Oxford English dictionary, post-truth is an adjective defined as "relating to or denoting circumstances in which objective facts are less influential in shaping public opinion than appeals to emotion and personal belief". In fact, the dictionary chose the term as its 2016 word of the year. Rochlin [2017], on the other hand, is more emphatic in stating that the phenomenon is a profound change in the regime of truth production, which has begun to emphasize personal experiences and beliefs over evidence.

It is important to note that post-truth cannot be confused with deliberate distortions, fake news and alternative facts. According to Silvio Waisbord [2018b], fake news ${ }^{8}$ has a history as old as the news itself and alternative facts are messages constructed in order to contradict scientific facts, that is, knowledge produced by institutions, such as science. In the author's view, what is new in post-truth is the rupture with the accepted model of "truth-telling" as a shared communicative practice based on science. In other words, the established knowledge and media model, based on reason and science, has lost significant authority in the post-truth

\footnotetext{
${ }^{3}$ https: / / bit.ly/3dNuLC1 (visited on June 29, 2020).

${ }^{4}$ https: / / bit.ly/31tR2Cy (visited on June 29, 2020).

${ }^{5}$ https: / / bit.ly /3dIy1yE (visited on June 29, 2020).

${ }^{6}$ https: / / bit.ly/2Zka1N5 (visited on June 29, 2020).

${ }^{7}$ https:/ / bit.ly/38a1Xma (visited on June 292020 ).

${ }^{8}$ According to Waisbord [2018b, p. 1], fake news is: "content featuring the style of conventional news intended to deliberately misinform".
} 
era. In this scenario, therefore, the visceral has triumphed over the rational [D'Ancona, 2018].

Liesbet van Zoonen [2012] studies the question of individuals' predilection for emotional and personal narratives and introduces the concept of I-pistemology, in which people from various places and in different phases of life begin to suspect knowledge coming from institutions and specialists, preferring their own experiences and emotions (personal beliefs). The term was coined to express a variety of phenomena that place the "I" at the center of knowledge. "Where epistemology is concerned with the nature, sources and methods [of] knowledge, then I-pistemology answers these questions from the basis of I (as in me, myself), and Identity, with the Internet as the great facilitator" [van Zoonen, 2012]. The author explains that personal experiences were mobilized with relative success by the New Right in Europe, but I-pistemology is also the result of critical theories and movements that identify knowledge as an instrument of power that needs to be challenged.

In this context, the formation of attitudes that were once regarded as a hallmark of critical thinking - now based on the productive cultivation of uncertainty and on the belief that the other may be deceiving us or that we may be deceiving each other - becomes post-truth's discursive environment, based on "circumstances in which objective facts have less influence in shaping public opinion than appeals to emotion and personal beliefs" [Dunker, 2017, p. 23]. The current logic of online social-network grouping represents a significant change in social organization and its relationship with the truth: there is an "inclination to close in on the supposed meaning too soon, to reach an understanding about the other too quickly, to alienate ourselves in the shelter of his/her image and thus close ourselves off from his/her words" [Dunker, 2017, p. 35]. In these groups, gathered amongst their own people, sharing beliefs and opinions, individuals end up suspending censorship. Suspending the censorship barrier has become "the official form of entertainment in the post-truth" era [Dunker, 2017, p. 36].

We have already drawn attention to the fact that experience has become the center of the mode of production of truth in contemporary culture [Sacramento and Paiva, 2020]. In this context, experience is well on its way to becoming the preferred legitimate source of knowledge about the truth. In the same sense, another type of authority is intensely valued: experiential authority. It emphasizes the testimonial character - I lived, I know - enunciating in the first person (I am the one who saw, who lived, who felt) the experience and narrative of a given event, establishing itself as the origin of a truth or as a document attesting that the narrated experience actually happened.

Part of the crisis of trust in which science is immersed in contemporary society also comes from communication of science itself because, since the arrival of digital platforms, scientific knowledge that was previously under the control of journalists can now be distributed by researchers through their own digital social networks. Wide dissemination, however, is hindered by the platforms themselves, which are based on algorithms, and the arrival of different actors who dispute the presentation and circulation of information. It is worth mentioning that, although there is this loss of reputation, media and science are still used as a means of thought validation [Oliveira, 2020]. Thus, in a post-truth context, it is not that the 
transmission of personal knowledge and experiential reporting is worth more than the understanding obtained from the pages of books, scientific articles or experts' statements. The point is that science matters when it can legitimize a previous belief system.

In this case, we cannot disregard the extent to which scientific denialism has been very strategic for the rise of the extreme right in the contemporary world.

Bolsonaro and Trump have been models of the affirmation of chloroquine and its derivatives as a panacea, to the detriment of the construction of a consensus in the scientific community about the fallibility of the drugs to treat those infected by the new coronavirus. This negationist stance, in the (new) extreme right, restructures a contrasting position between "we" and "they," in which "we" are the

(neo)liberal-conservatives, who should have the right to use the drugs we consider effective, and "they" are often characterized as leftists and communists, who wish to prevent the use of a drug that could be effective.

Waisbord [2018a] proposes that there is an "elective affinity" between post-truth and the recent upsurge of right-wing populism's mix of anti-elite sentiments, frustration with the failings of democracy and resentment towards the uneven effects of globalization on national economies: "the current 'populist moment' is grounded in structural trends in contemporary societies" [Waisbord, 2018a, p. 2]. Although the author is careful to point out that populism is the outcome of a complex web of socio-cultural developments, he argues that the binary vision of the world as neatly and inevitably divided between two irreconcilable camps - the people versus the political, economic, cultural and scientific elites - thrives under the current conditions of digital media and its new forms of mediation. As (neo)conservative populist presidents around the globe have embodied post-truth communication as a distinctive feature of contemporary politics, Waisbord [2018a, p. 9] asserts that "[e]ven when in power, populism insists on this vision of truth as necessarily divided".

The case of Jair Bolsonaro is exemplary. Based on an analysis of Brazil's 2018 presidential elections, Cesarino [2020a] and Cesarino [2020b] sought to deepen the debate on the close relationship between post-truth and populism. According to the scholar, Bolsonaro shared immediate personal experiences and beliefs in videos circulating on WhatsApp and other social media. In these, "Bolsonaro himself indulges in statements where he freely contradicts statistics based on 'feelings' or a 'vision' of 'reality'". [Cesarino, 2020b]. In addition, hidden causal links emerged through the online proliferation of conspiratorial narratives, regularly delivered through WhatsApp, YouTube channels, and controversial tweets. Finally, endless online debates about the denial of evidence often lead to decisions based on the antagonistic polarization of society and the strengthening of group boundaries.

In this article, we understand Bolsonarism (in Portuguese, bolsonarismo) as the current form of organization of Brazilian (neo)conservatism that, digitally enhanced by post-truth communication, ascended to power in 2018. Understanding that distrust of traditional media (such as radio and television stations, as well as major newspapers) is also a characteristic of Bolsonarism - after all, these vehicles are often considered to be agents spreading communism and cultural Marxism [Cruz, 2019] - the president's weekly lives may be considered the most direct, unfiltered and spontaneous form of communication 
to his political allies. According to Cesarino [2020a, p. 97], by urging his supporters to turn off the television and get information through his weekly live streams, the then presidential candidate solidified an exclusive media channel that, on the one hand, isolates part of the public from the contradictory and from differences of opinion and, on the other hand, emotionally mobilizes his supporters by incessantly fabricating enemies of the people. The continued use of live streams after the 2018 election campaign ended, now as a government communication tool, reiterates the strategy whereby Jair Bolsonaro speaks his version of the truth more directly to his supporters, without interventions or counterpoints.

\section{Results and} discussion

\section{Questioning the delay inherent in following the scientific method}

Facebook is regarded as having been the most important digital platform in terms of the consolidation of Bolsonaro's image as an alternative to the political elite and traditional media [Almeida, 2019; Goldstein, 2019], in addition to providing a channel through which communication happens more directly with the public. Every Thursday, starting at 7pm, the Brazilian president presents a 'live' on his official Facebook page with a weekly summary of the actions performed by his government. The lives are audiovisual content that value intimacy and spontaneity, with a certain degree of formality and decorum. The ambiance is sober - consisting of a large wooden table, a bookcase full of books in the background and participants dressed formally (as shown in Figure 1).

Nevertheless, in it, the president seeks to talk to supporters in an informal tone and offer them a space for chatting among themselves. Since the 2018 presidential race, Bolsonaro has used this channel to attack the mainstream media and turn the population towards the Internet, where he has more time and space to propagate his political agenda [Goldstein, 2019]. Therefore, Bolsonaro's weekly lives work as a communicative device [Charaudeau, 2010] in which the president constructs emotional scenarios without the traditional mediatic filters to produce the intended pathemic effects of his discourse.

One of Bolsonaro's biggest concerns in managing the pandemic is the delay in the formation of a global scientific consensus on the use of (hydroxy)chloroquine for the treatment of patients suffering from COVID-19. As he repeatedly questions scientific logic, as well as methods employed to produce knowledge and the delay these cause in developing solutions to the crisis, the Brazilian president paints a discursive scenario colored with the hope that "we will beat this wave and we will grow," since, after all, "it seems like God is Brazilian". It is worth mentioning that the president employs the sentiment of "hope" now in the same way he did in 2016 when, as a congressman, he promoted another substance without scientific proof, synthetic phosphoethanolamine, as a possible cure for cancer [Monari, 2019].

According to Bolsonaros's rhetoric, it is necessary to speed up the process and believe that "God willing, this will be shortly confirmed as a medication to cure all those infected with COVID-19 [sic]". As he insists, "I am Catholic, my wife is evangelical... We believe in God, God empowers us... He doesn't choose the qualified, he qualifies the chosen, right?" [Bolsonaro's weekly Facebook live stream on March 26, 2020]. Bolsonaro's political career has been marked by his becoming an agent of information disorder, promoting both an evangelical-conservative agenda and a dogmatic belief system [Almeida, 2019; Romancini, 2018]. It is not 


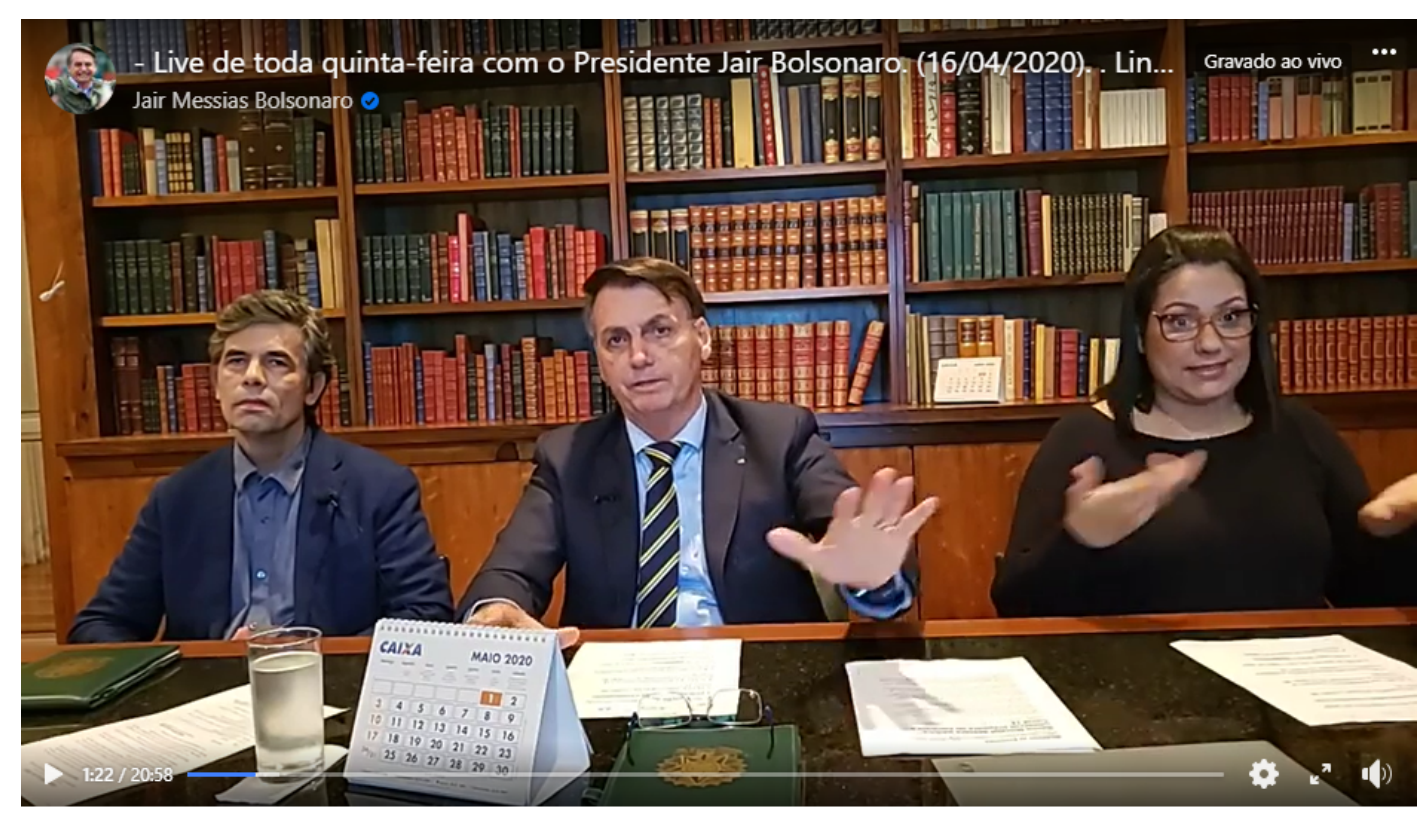

Figure 1. Ambiance of Bolsonaro's weekly live streams. Source: live stream on April 16, 2020 - Bolsonaro's page on Facebook.

necessarily scientific denialism. These narratives do not exclusively seek to annihilate science, but rather to use science in order to corroborate a previous belief system. In other words, it is less denialism and more affirmativeness. What he seeks to affirm is the belief that institutions, such as science and journalism, may be hiding the truth that religion and God can provide.

In this light, he shares the episode in which he was asked by the press "if I couldn't wait for the final [scientific] proof... I asked the guys: How long, more or less? Nobody wanted to answer... Six months from now? There are men, women, elderly people and they are in a complicated situation, right?". To him, the solution is as simple as: "Get tested, confirm the coronavirus, take the drugs!". As Bolsonaro tries to establish positive expectations for the effectiveness of the drugs, he repeatedly insists that lives can only be saved if bold actions are immediately taken: "I spoke to the Secretary of Defense today, I talked to him about the production of this material in the Army's chemical-pharmaceutical laboratory in Rio de Janeiro, and he said that the order was given and is in full swing" [Bolsonaro's weekly Facebook live stream on March 26, 2020].

To consolidate the mix of hope and urgency staged on his Facebook live streams, Bolsonaro affirms that "Americans are researching this drug over there," as well as "we have news from dozens of places in Brazil of people treated with it here and it is working, so there is nothing miraculous, it has been working". For him, there is no need to wait for science to tell us the risks of taking a drug that has been on the market "since I was born in 1955". [Bolsonaro's weekly Facebook live stream on March 26, 2020].

A few weeks later, during the Facebook live stream on April 16, 2020, Bolsonaro introduced his new Secretary of Health, Nelson Teich, to the public. The president shared on camera his dissatisfaction with the actions of the former secretary, Luiz Henrique Mandetta, when saying: “(...) the point that didn't really fit with [my] 
idea was exactly the concern with the issue of employment in Brazil. (...) as I have always said, it [Brazil] is a patient with two serious problems [coronavirus and unemployment]". Although acknowledging that Mandetta is a doctor and had made administrative decisions based on scientific guidelines and methods, Bolsonaro insists that more urgent actions must be taken in order to save the economy and people's jobs as well: "Mandetta, his methodology as a physician, I respect him, was focused almost exclusively on the issue of life, health. But we know what the side effects of a very strict quarantine is doing to people. The humblest people have lost their jobs, or their income, in the case of informality" [Bolsonaro's weekly Facebook live stream on April 16, 2020].

By agreeing with Bolsonaro's bold opinions and urgent actions, Dr. Teich, an oncologist, seemed to ignore the time science requires to produce knowledge. Teich said that, although the efficacy of chloroquine and hydroxychloroquine in treating COVID-19 had not been scientifically proven, it was soon to be so: "We have several studies here and I believe that this will come in a relatively short time, we will not need to wait for this time you've said, it will come faster" [Bolsonaro's weekly Facebook live stream on April 16, 2020]. By communicating the belief that science will "solve the problem" quickly, Teich seeks to reaffirm people's hope that the government can control the virus.

Bolsonaro's and Teich's statements represent an opportunistic use of science, in which the time required to produce scientifically substantiated solutions to the pandemic is questioned for the sake of their political goals. In other words, they pressure physicians to prescribe (hydroxy)chloroquine as a treatment for COVID-19 patients and support the flexibilization of social isolation policies as a way to gain popular support for the idea that returning to work sooner poses no health risks and could potentially prevent an economic crisis. It is important to point out that, on May 15, 2020, Dr. Teich left the Department of Health before completing a month in office and after disagreeing with Bolsonaro on the use of (hydroxy)chloroquine and the flexibilization of social isolation.

\section{Overvaluation of personal experiences}

Personal accounts of recovery from COVID-19 were one of the tactics used by Bolsonaro to convince the population to use chloroquine and hydroxychloroquine to treat the disease. Although several studies conducted in Brazil and abroad have shown that both drugs are ineffective in combating the new coronavirus, Bolsonaro incites distrust of a scientific narrative, preferring to be guided by the testimonies of those who have taken the substances and have had good results. The Brazilian president's positioning reflects Trump's statement, made in an interview on May 18,2020 , in which the U.S. president admits he decided to take the drug after receiving many positive letters about its effectiveness: "A couple of weeks ago I started taking it. Because I think it's good. I've heard a lot of good stories and if it's not good, I'll tell you: right, I'm not going to get hurt by it. (...) all I can tell you is so far, I seem to be $\mathrm{OK}^{\prime \prime} .9$

\footnotetext{
${ }^{9}$ https: / / www.youtube.com/watch?v $=$ cGTfW2gb2SI (visited on June 26, 2020).
} 
As we observe in this article, post-truth politics imply an indifference to the truth measured by institutions recognized as experts and a preference for personal and collective experience as a fundamental characteristic of truth. The strategic management of most peoples' ignorance of science and desire to affirm their prior beliefs has led, paradoxically, to recognition of the authority of a charismatic leader who seeks to claim for himself the confidence lost in institutions by stimulating and propagating generalized distrust. Since trust is a pragmatic element of faith, truth is increasingly being intentionally defined as what makes sense to certain groups. After all, trust is in the eyes of the beholder: it is the beholder who evaluates and legitimizes a feeling of trust [Sacramento and Paiva, 2020].

On March 26, 2020, Bolsonaro mentioned hydroxychloroquine for the first time in his weekly Facebook live streams. It is interesting to note that he does not just talk about the drug, he also shows two packages of it, one displaying its commercial name (Reuquinol) and the other a generic version (as shown in Figure 2). Within the scope of the communicative device, we understand that Bolsonaro's Facebook weekly live streams use digital resources to create an effect of proximity to the public without, however, rejecting discursive and gestural components that are specific to the medium of television. When Bolsonaro exhibits the two boxes of (hydroxy)chloroquine on camera, he places himself in the talk show universe, in which TV presenters advertise a certain product and exhibit it to the public through the lens of a camera. In this common domain, the president aims to awaken in the public's memory images similar to those of famous TV presenters, using an informal tone that builds an environment of confidence and trust - it is as if Bolsonaro had recommended a product to a friend.

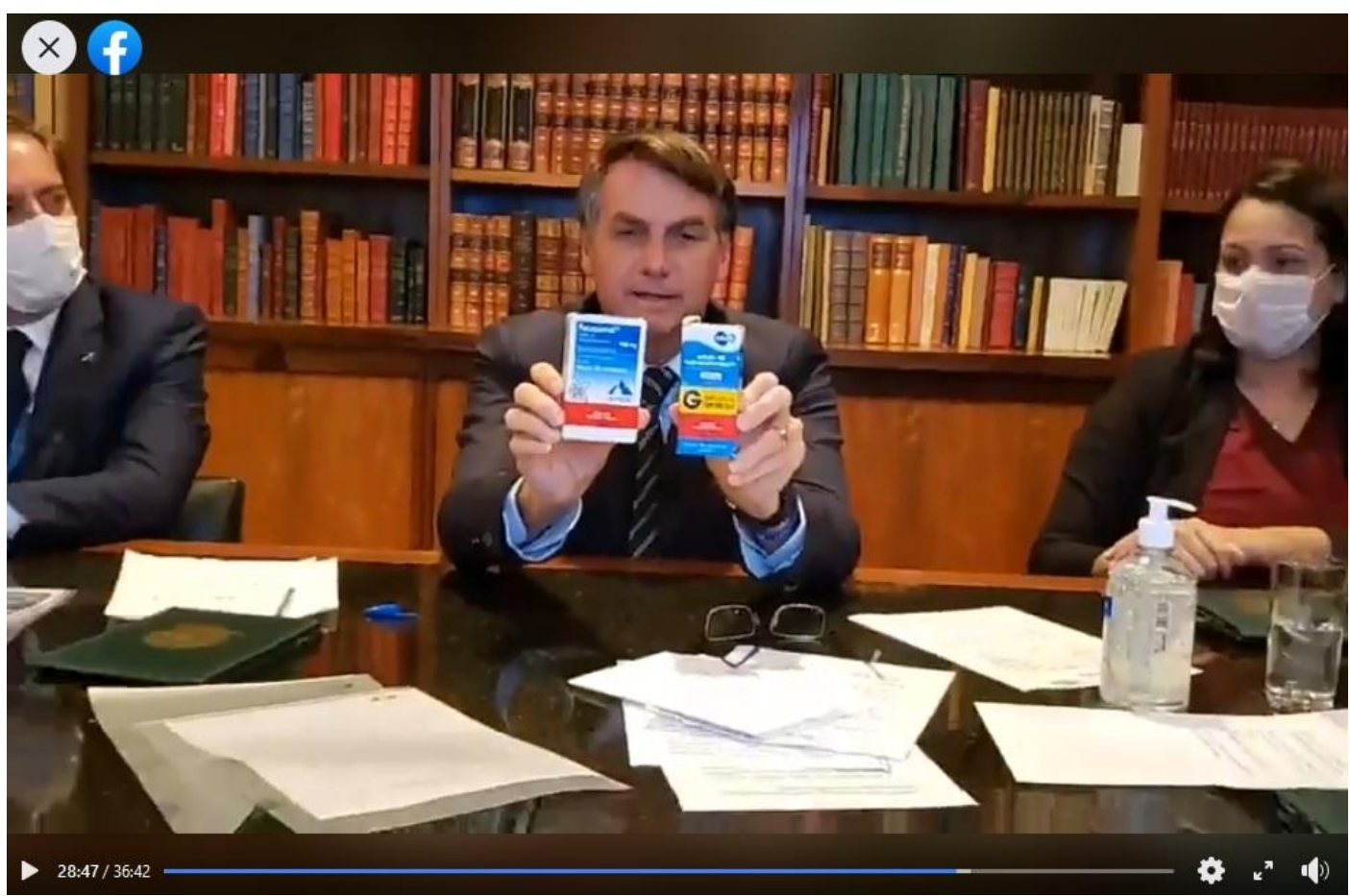

Figure 2. Bolsonaro presents (hydroxy)chloroquine to the public. Source: live stream on March 26, 2020 - Bolsonaro's page on Facebook. 
It is also on March 26, 2020 that the dispute between empirical evidence and alternative facts about the drugs begins (skepticism of scientific research compared to trust in personal reports). Bolsonaro uses testimonials to create a narrative parallel to that of science, such as "We have news from dozens of places in Brazil where people are treated with this and it's working $(. .$.$) " [Bolsonaro's weekly$ Facebook live stream on March 26, 2020] or "There are lots of people who say they've healed with it. Back in São Paulo, we have Kalil, now the governor of Roraima... Denarium was affected by COVID and took hydroxychloroquine with azithromycin (...)" [Bolsonaro's weekly Facebook live stream on May 21, 2020]. Bolsonaro, as an enunciative subject within a dramatization process, uses this information to suggest a common environment and share it with the viewer: a world in which many people are cured of COVID-19 by taking (hydroxy)chloroquine.

In Bolsonaro's live transmissions, when he talks about his mother, he targets the partiality of individuals towards emotional and personal narratives, which was addressed by van Zoonen [2012] in the development of I-pistemology. He says, "My mother is 93 years old. It's obvious that she'll take [the drug], democratically she'll take [it], no problem at all" [Bolsonaro's weekly Facebook live stream on April 4, 2020] and "I want to leave a testimonial of mine here: my mother is 93 years old, if a brother of mine, a sister says, 'look, it's positive for her' (...) we're going to go for chloroquine" [Bolsonaro's weekly Facebook live stream on May 14, 2020]. The phrase "it's positive for her," followed by hands and head gestures of agreement, work to reinforce the listeners' sentiment of trust in the president; after all, even the president's mother can get sick and take the drug as part of his proposed treatment for COVID-19.

Bolsonaro's opportunistic use of science is evident when he presents expert testimonials (from doctors and scientists) to convince the population that chloroquine and hydroxychloroquine are appropriate treatments for the new disease. The testimony of cardiologist Roberto Kalil Filho, for example, was used by Bolsonaro in two lives (April 9, 2020 and May 14, 2020) to reiterate the statement that the drugs may have saved the life of the doctor, who was diagnosed with the disease. The politician states in the transmission "(...) I had talked to Dr. Kalil and he was in critical condition, he confessed, said he used chloroquine" [Bolsonaro's weekly Facebook live stream on April 4, 2020].

It is important to point out in Kalil's testimony that he never claims that hydroxychloroquine saved his life. In an interview with the Brazilian newspaper Folha de São Paulo [2020], ${ }^{10}$ he said that he agreed to take the drug, but he did not credit his improvement only to it, because he took a range of medications including corticosteroids, anticoagulants and antibiotics. Bolsonaro, however, omits this fact in the two transmissions in which he presents the doctor's testimony, inducing the public to think that Kalil was cured of COVID-19 only with the help of hydroxychloroquine. This act of disinformation (of taking data out of its proper context) contributes to the belief that the drug saves lives.

Kalil's testimony is part of a series of videos posted on Jair Bolsonaro's official Facebook page in order to strengthen his alternative narrative favoring the use of chloroquine and hydroxychloroquine without scientific proof. Between March 21,

\footnotetext{
${ }^{10}$ https:/ / bit.ly/2IjjN6J (visited on June 25, 2020).
} 
2020 and April 8, 2020, eight videos were posted with speeches given by doctors, scientists and journalists who sought to describe the drugs and their benefits. In addition, authority discourse [Oliveira, 2020] is also summoned in the live streams when the president comments on the decisions of professional entities such as the Federal Council of Medicine and the State of Amazonas Regional Council of Medicine.

\section{Emphasis on individuals' freedom of choice}

"Faith in God, work, trust. I believe in the Brazilian people" [Bolsonaro's weekly Facebook live stream on March 26, 2020]. To convince the population of the efficacy of the use of chloroquine and hydroxychloroquine in the treatment of COVID-19, Bolsonaro stages a populist discourse that polarizes the world into two irreconcilable truths: the truth of the people against that of the elites, or even better, God's truth against that of His enemies. As Waisbord argues [2018a, p. 3], "populism's anti-elitism is also manifest in its opposition to facts and truth determined by knowledge-producing elites such as scientists and experts". In this sense, to dispute the truth of science in the context of the century's biggest health crisis, the Brazilian president builds a discursive scenario around freedom of religion that strategically serves to justify his government's neoliberal rationality that delegates the decision to use or not use the drugs to the personal judgment of each sovereign individual and exempts the State from any responsibility for medical treatment with the drugs. Therefore, by strengthening the polarization between "us" (the people who have faith in God) and "them" (the opportunistic elites that believe that scientific norms determine reality), Bolsonaro reinforces the conflict between autonomy and control; individual sovereignty and collective submission.

During the live stream on May 21,2020, by reaffirming the Christian character of his government and communicating that he had had a video conference with Catholic political groups earlier that day, Bolsonaro said he treats all religions with respect, verbalizing his belief that freedom is more important than life itself: "Freedom is the most sacred thing we can have here on Earth. [...] those who give up part of their freedom to have a little more security, deserve neither one thing nor the other. So, freedom above all. Freedom is priceless" [Bolsonaro's weekly Facebook live stream on May 21, 2020]. The discourse on "freedom of religion" as transcendent moral authority served as a preamble to address the document released by the Brazilian Department of Health on the previous day that expanded the possibility of using hydroxychloroquine for the early treatment of COVID-19 patients, despite scientific research not proving its effectiveness and warning about possible health risks.

According to the new protocol ${ }^{11}$ - and in line with the minimal state rationality - citizens must sign an "Informed Consent Form," 12 whereby the government disclaims any responsibility for treatment with (hydroxy)chloroquine and patients accept "the risks mentioned [herein] and give permission/voluntary authorization for the drugs to be used in the manner described [herein]". In the post-truth digital regime of politics that exists within the current form of

\footnotetext{
${ }^{11}$ See: https: / bit.ly/35wWztJ (visited on September 12, 2020).

${ }^{12}$ See: https:/ / bit.ly/2UuX01t (visited on June 26, 2020).
} 
neoliberalism, patients are left with the option to "freely" decide to take a drug in spite of the fact "that there is no guarantee of positive results for COVID-19 and the proposed drug may even have side effects," such as "reduction of white blood cells, liver dysfunction, cardiac dysfunction and arrhythmias, and changes in vision due to damage to the retina". In addition, Bolsonaro encourages the entrepreneurial subjectivity of his supporters by saying that "the first person to worry about the risk group is you who have a father, grandfather, great-grandfather inside the house. You should not wait for the government to do something" [Bolsonaro's weekly Facebook live stream on March 26, 2020].

During the live stream on March 26, 2020 Bolsonaro ennobles himself as the man "chosen by God" to fight the people's fight - claiming that "by God's will" chloroquine and hydroxychloroquine "will soon be confirmed as a remedy to cure all those with COVID-19". This was despite the concern raised in Brazil by the leftist media and scientists defending pre-determined visions of politics. The populist leader of the largest South American nation embodies the use of post-truth communication as a distinctive feature of contemporary politics [Waisbord, 2018a, p. 2]. Despite being imbued with emotional images of a religious character and an apparent concern with the masses, Bolsonaro's audiovisual performance is guided by a neoliberal governmentality committed to the interests of the business elites. As suggested by former Brazilian Secretary of Health Henrique Mandetta, the dispute waged by the Brazilian president in favour of chloroquine and hydroxychloroquine is an attempt to stimulate an early return to work: "The idea of giving chloroquine, in the mind of the world's political class, is that, if you have the drug, people go back to work" ${ }^{13}$ As Bolsonaro stated during the Facebook live stream on May 14, 2020, "today we had a meeting with businessmen. A very important group of people who decided to come in, discuss this matter so that we can make the economy work because we save jobs, and saving jobs is saving lives too".

As neoliberalism reorganizes the human sense of perception, Cvar and Bobnič $[2019$, p. 80] argue that the phenomenon of post-truth cannot be properly understood without taking into account the historical circumstances in which this governmentality has been optimized. Therefore, the Brazilian president plays with the complex set of emotions that derive from the notions of self-responsibility, autonomy and freedom of choice to produce the intended pathemic effect of his discourse. To illustrate our point, during the live stream on May 21, 2020, in a grotesque discourse that produces the effects of power inherent in the position he holds, Bolsonaro compared the ordinary act of drinking a Coca-Cola to taking hydroxychloroquine. In the contemporary digital communicative device ambiance set up by Bolsonaro's weekly Facebook live streams, in which institutional codes cohabit with presidential intimacy and spontaneity, the Head of the Nation wears casual clothes - including a soccer jersey - and sits in front of an imposing bookcase that summons knowledge, to produce enunciations with the status of truth (as shown in Figure 3): "People say that I'm wrong, but I drink Coca-Cola and I get well. Let me take what I want here, it's like chloroquine: those who want to take [it], take it; those who don't want [to], don't take it" [Bolsonaro's weekly Facebook live stream on May 21, 2020].

\footnotetext{
${ }^{13}$ https:/ / bit.ly / 2NHov4p (visited on June 15, 2020).
} 


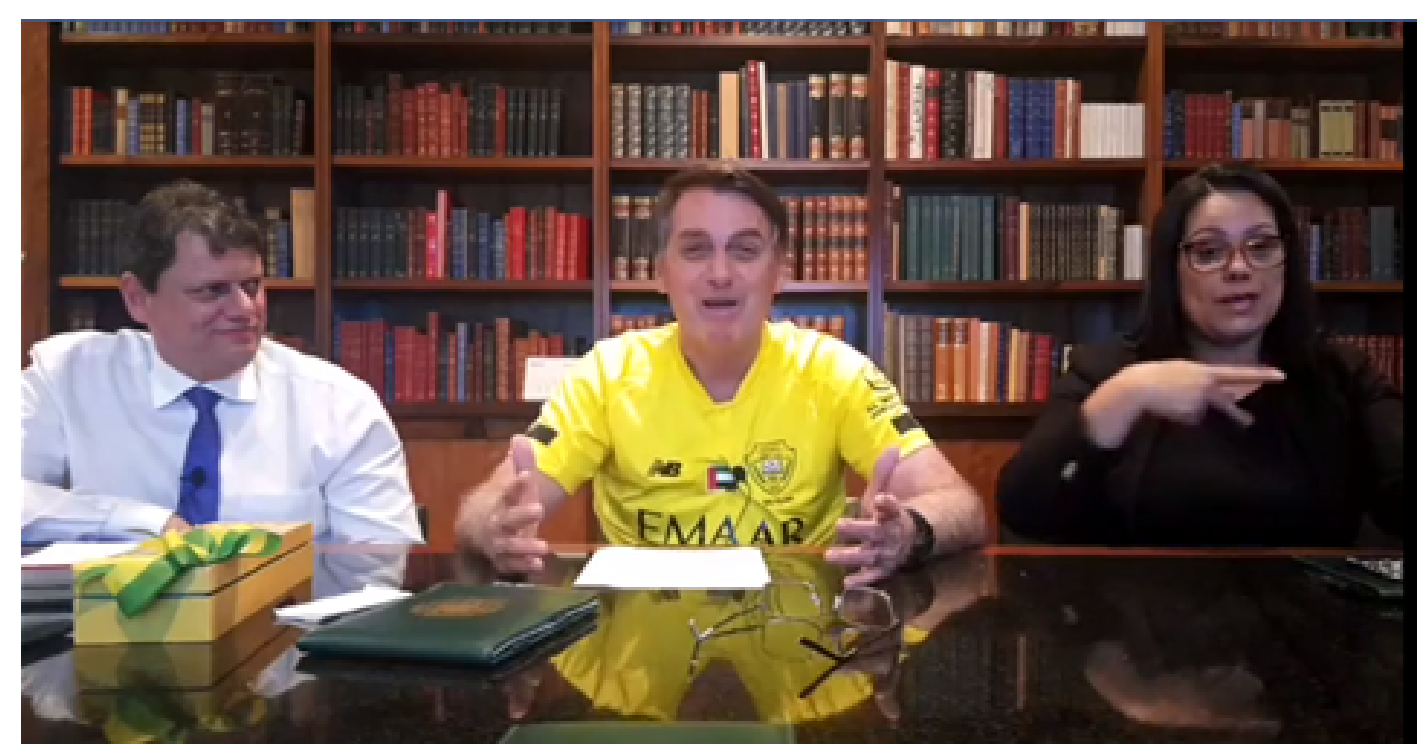

Figure 3. The institutional blended with the intimate. Source: live stream on May 21, 2020 Bolsonaro's page on Facebook.

The association of "freedom of religion" and "freedom of choice" to reinforce the polarization between conservative and progressive groups can therefore be understood as a post-truth communication strategy that forms identity politics by "reaffirm[ing] and renew[ing] social, political, ideological and cultural community without regard [to] their correspondence to reality" [Waisbord, 2018a, p. 14]. By making viral his arguments in favour of individuals' freedom to choose to take (hydroxy)chloroquine to treat COVID-19, Bolsonaro creates a "community of belief" [Waisbord, 2018a, p. 5] bonded by emotions directly derived from concepts that have historically been the basis for neoliberal rationality, such as freedom, individualism, self-responsibility, autonomy and entrepreneurship.

\section{Conclusions}

Through the investigation of Bolsonaro's weekly Facebook live streams, we observed that the new coronavirus pandemic has reinforced right-wing populism in Brazil. The crisis triggered by the federal government was against science, and often in favour of affirming the president's opinion. In the case of chloroquine and hydroxychloroquine, there has been a war against science that treats scientific paradigms and methods as a kind of outdated intellectualism. After all, according to Bolsonaro, personal opinion and experiences should be seen as the most fundamental elements in establishing true knowledge.

The phenomenon of post-truth is inseparable from democracy of opinion and the liberal conception of information, according to which truth results from a competition between all content in the market of ideas, whether falsified or authentic. By making all of us competent citizens on political issues, the democratic system enhances our critical sense regarding official truths without diminishing our credulity. The democratic model postulates the existence of active, rational, educated and informed citizens, but what exactly does it mean to be informed? Does being informed, if not objectively, but at least fairly, require having a lot of time and discernment? 
In many ways, Bolsonaro's enunciations, like Dr. Roberto Kalil's testimonies, resemble those of a salesman. This even led Kalil to apologize, saying he was not a poster boy for hydroxychloroquine. The main feature of this sales pitch is to eliminate all consideration of reality and completely ignore the truth. Given this feature, one cannot blame the seller of the idea for providing an erroneous representation of reality, because his words are completely disconnected from it and, therefore, free from any concern for the truth. After all, his main commitment was to promote the drug as a solution to the problem.

Although admitting that a sales discourse is not a prerogative of contemporary post-truth, we can infer that there are two main reasons why Bolsonaro uses it in his discourse: at the social level, the propensity to express convictions devoid of sufficient knowledge of the issues considered and, at the intellectual level, the expansion of a skepticism that denies the possibility of an objective knowledge of reality.

During the outbreak of this health crisis, Bolsonaro's weekly lives on Facebook not only minimized or dismissed the warnings about the problem that the COVID-19 represents for public health, but also ridiculed politicians, experts and journalists who sought to affirm something different or, at least, have greater caution and rigor when investigating information about the effectiveness of the drugs. Instead of preparing Brazilian society to face this serious health crisis, Bolsonaro adopted a strategy of blaming everyone for the system's failures, except himself. Thus, he would end up being the one who provided the "vertical isolation" solution to the economic crisis and had the (hydroxy)chloroquine solution for the collapse of the health system. He had the solution all the time, but no one was listening to him.

References

Almeida, R. (2019). 'Bolsonaro presidente: conservadorismo, evangelismo e a crise brasileira'. Revista Novos Estudos (Cebrap) 38 (1), pp. 185-213. https://doi.org/10.25091/s01013300201900010010.

Cesarino, L. (2020a). ‘Como vencer uma eleição sem sair de casa: a ascensão do populismo digital no Brasil'. Revista Internet $\mathcal{E}$ Sociedade 1 (1), pp. 91-120. URL: https://revista.internetlab.org.br/serifcomo-vencer-uma-eleicao -sem-sair-de-casa-serif-a-ascensao-do-populismo-digital-no-brasil/.

- (28th January 2020b). What the Brazilian 2018 elections tell us about post-truth in the neoliberal-digital era.

URL: https://culanth.org/fieldsights/what-the-brazilian-2018-electio ns-tell-us-about-post-truth-in-the-neoliberal-digital-era.

Charaudeau, P. (2007). 'Pathos e discurso politico'. In: As emoções no discurso. Ed. by I. L. Machado, W. Menezes and E. Mendes. Vol. 1. Rio de Janeiro, Brazil: Lucerna, pp. 240-251.

- (2010). 'A patemização na televisão como estratégia de autenticidade'. In: As emoções no discurso. Ed. by E. Mendes and I. L. Machado. Vol. 2. Campinas, Brazil: Mercado Letras.

Cruz, O. (2019). '¿Por qué ganó Bolsonaro en Brasil?' Revista Mexicana de Sociologia 81 (3), pp. 665-675. https://doi .org/10.22201/iis.01882503p.2019.3.57925. 
Cvar, N. and Bobnič, R. (2019). 'Truth, post-truth, non-truth: new aestheticized digital regime of truth'. In: Post-truth and the mediation of reality: new conjunctures. Ed. by R. Overell and B. Nicholls. Cham, Switzerland: Palgrave Macmillan, pp. 79-103. https://doi.org/10.1007/978-3-030-25670-8_5.

D'Ancona, M. (2018). Pós-verdade: a nova guerra contra os fatos em tempos de fake news. Barueri, Brazil: Faro Editorial.

Dunker, C. (2017). 'Subjetividade em tempos de pós-verdade'. In: Ética e pós-verdade. Ed. by C. Dunker, C. Tezza, J. Fuks, M. Tiburi and V. Safatle. São Paulo, Brazil: Brasiliense.

Goldstein, A. (2019). 'O sucesso das "guerras culturais" na campanha de 2018: Bolsonaro no Facebook e Instagram'. Revista Inter-legere - Revista da Pós-Graduação em Ciências Sociais da UFRN 2 (26), c20148. https://doi.org/10.21680/1982-1662.2019v2n26ID20148.

Monari, A. C. P. (2019). ‘O "milagre” da pílula: os efeitos da mídia na opinião pública sobre o caso da fosfoetanolamina sintética'. Dissertação de mestrado. Bauru, SP, Brazil: Universidade Estadual Paulista. URL: http://hdl . handle. net/11449/183497.

Oliveira, T. (2020). ‘Desinformação científica em tempos de crise epistêmica: circulação de teorias da conspiração nas plataformas de mídias sociais'. Fronteiras - estudos midiáticos 22 (1). https://doi.org/10.4013/fem.2020.221.03.

Rochlin, N. (2017). 'Fake news: belief in post-truth'. Library Hi Tech 35 (3), pp. 386-392. https://doi.org/10.1108/lht-03-2017-0062.

Romancini, R. (2018). 'Do "kit gay" ao "monitor da doutrinação": a reação conservadora no Brasil'. Revista Contracampo 37 (2), pp. 1-22. https://doi.org/10.22409/contracampo.v0i0.1102.

Sacramento, I. and Paiva, R. (2020). 'Fake news, WhatsApp e a vacinação contra febre amarela no Brasil'. MATRIZes 14 (1), pp. 79-106. https://doi.org/10.11606/issn.1982-8160.v14i1p79-106.

van Zoonen, L. (2012). 'I-Pistemology: changing truth claims in popular and political culture'. European Journal of Communication 27 (1), pp. 56-67. https://doi.org/10.1177/0267323112438808.

Waisbord, S. (2018a). 'The elective affinity between post-truth communication and populist politics'. Communication Research and Practice 4 (1), pp. 17-34. https://doi.org/10.1080/22041451.2018.1428928.

- (2018b). 'Truth is what happens to news: on journalism, fake news and post-truth'. Journalism Studies 19 (13), pp. 1866-1878. https://doi.org/10.1080/1461670x.2018.1492881.

\section{Authors}

Ana Carolina Pontalti Monari. Ph.D. candidate at the Postgraduate Program in Health Information and Communication (PPGICS) at Fundação Oswaldo Cruz (Fiocruz). Master in Communication and journalist at Universidade Estadual Paulista (Unesp). Doctoral fellow at the Coordination for the Improvement of Higher Education Personnel (Capes) and member of the Center for Studies in Communication, History and Health (Nechs - Fiocruz/UFRJ).

E-mail: capmonari@gmail.com. 
Allan Santos. Ph.D. candidate at the Postgraduate Program in Communication and Culture at the School of Communication at the Federal University of Rio de Janeiro (ECO-UFRJ) and researcher in the Center for Studies in Communication, History and Health (NECHS — Fiocruz/UFRJ). E-mail: allansantos29ny@gmail.com.

Igor Sacramento. Ph.D. in Communication and Culture at UFRJ and professor at the Post-Graduate Program in Communication and Culture at UFRJ and at the Post-Graduate Program in Information and Communication in Health at Fiocruz. $\mathrm{CNPq}$ Research Productivity Scholarship. Leader of the Center for Studies in Communication, History and Health (Nechs — Fiocruz/UFRJ).

E-mail: igorsacramento@gmail.com.

How to cite

(C) The Author(s). This article is licensed under the terms of the Creative Commons Attribution - NonCommercial - NoDerivativeWorks 4.0 License.

ISSN 1824-2049. Published by SISSA Medialab. jcom.sissa.it 